\title{
THE IMPLEMENTATION OF MULTIPLE INTELLIGENCES IN ENGLISH LANGUAGE TEACHING
}

\author{
Duwi Sulistiyowati, Joko Nurkamto, Dewi Sri Wahyuni \\ English Education Department \\ Teacher Training and Education Faculty \\ Sebelas Maret University of Surakarta
}

\begin{abstract}
This reseacrh describes: (1) the implementation of Multiple Intelligences (MI) in English language teaching (ELT (2) the benefits and the challenges of implementing MI. This is descriptive qualitative research with purposive sampling which data are collected through observation, interview, and document analysis and analyzed through interactive model. The result shows that: (1) the implementation of MI in ELT requires: (a) MI-based lesson plan, (b) activities involving apperception and strategy; (c) teacher's role as facilitator, input provider, monitor of learning, need analyst, motivator, organizer, controller, language demonstrator, material developer, and counsellor; (d) the students' roles as participant, active learner, intelligence user, and responder; (e) instructional and authentic materials; (f) the evaluation covering achievement and process of learning; (2) the benefits of implementing MI are creating fun and effective teaching, promotting students' participation, and facilitating student's intelligences, while the challenges of implementing MI are managing classroom dynamic and treating the student with special needs.
\end{abstract}

Keywords: multiple intelligences, English language teaching and learning

\section{INTRODUCTION}

English is important means of communication. For now and many years to come it is and will be a vital linguistic tool in many people's different life fields such as, business, academic, and tourism in international level. It is a lingua franca which is used in communication between people whose native languages are different each other. (Harmer, 2001: 1-2). Consequently, it is necessary for people to master English.

In Indonesia, English is regarded as one of the subjects in formal elementary education. It is taught as local content. It is stated that the program of English teaching at elementary school is conducted in order to prepare the elementary students to learn
English at Junior High School. (BSNP, 2006:142).

Language learning is defined by Brown (2000: 14) as "Learning to communicate genuinely, spontaneously, and meaningfully in the second or foreign language". Meanwhile, Widdowson (2008: 3) states that learning language deals with how the learners develop their competence and performance. Competence refers to the knowledge about abstract linguistic rules of the language, while performance is the manifestation of the knowledge into real act. In addition, Attard et.al (2010: 12), recognize that learning language is learnercentred activity. In learning the learners are the core reason of the act of the process. All 
the activities in language learning are conducted as the facilities for them to learn.

Language teaching is an activity performed by teacher with the objective of developing learners' ability to produce correct sentences and to use them appropriately. Widdowson (2008: 1) states that those two abilities are important in human interaction which is done by listening, speaking, reading, and writing (LSRW).

Teaching English to elementary students is very beneficial. Children learn a second language better than adults. It is caused by the reason that children are in the stage of critical period that enables children to get their best brain's capacity (Cameron 2001:13). Supporting Cameron, Clark (1997 :322), said that to master English, people should start learning as early as possible. It is because young age is the proper time to study English or other foreign languages.

Teaching English to children has three principles. First, referring teaching approaches on the natural capacities and instincts children bring to the classroom. Second, developing a positive response to languages and to language learning (attitude goals) as well as to what they learn (content goals). Third, making sure that real language use is set up in various forms and is made as part of the process of learning not just as intended product. (Halliwel, 2008: 9).

Now Multiple Intelligences (MI) gains popularity. It derives from the basic view proposed by Howard Gardner saying that human intelligence as having multiple dimensions consisting of eight types of intelligence, those are: Linguistic Intelligence, Bodily-Kinesthetic Intelligence, Spatial-visual Intelligence, Musical Intelligence, Logical-Mathematical Intelligence, Intrapersonal Intelligence,
Interpersonal Intelligence, and Naturalist Intelligence. Each person is seen to be different in strength toward the types of intelligence (Amstrong, 2009: 6-7).

MI gives teachers new paradigm in viewing their students. Before MI exists in education, teachers usually valued their students based on their academic achievement score which was obtained by formal test. In this case, the students are regarded as smart if they could achieve good score for the test. In contrast, MI broadens students' talent. It concerns on receiving all students to have eight intelligence types. All students are smart, but in different ways.

Chatib (2010: 108) defines MI as teaching strategy for all subjects that focuses on how teachers bring their teaching style in order that it is easy for students to understand. The activities are created based on each of different intelligences. All those are aimed at facilitating students to achieve the learning objectives.

As well as general classroom, in English classroom which is conducted with MI a teacher should consider syllabus, lesson plan, learning activities, roles of teacher, roles of learners, teaching materials, and evaluation. Syllabus is a set of learning plan in one subject matter with specific theme include standard of competency, basic competency, material, indicators, assessment, time allotment, and resources of teaching developed by each school (Mulyasa, 2006: 176). It should be provided in teaching and learning process. Meanwhile, lesson plan is defined as a plan representing the procedure and the management of learning process to reach the basic competency that is stated in the content standard (2006: 212). Chatib (2012: 192), adds that a lesson plan used in MI classroom covers three parts those are 
header, content, and footer. The lesson plan states several special characteristics reflecting MI those are aperception, teaching strategy, problems, new idea, and special moment.

Chatib (2012: 87) states that basically in implementing MI in teaching and learning process a teacher has to involve two essential parts, those are apperception and strategy. Apperception covers alpha zone, scene setting, pre-teach, and scene setting. Meanwhile, strategy is the part of MI that the teacher concerns on determining how the lesson should be arranged. Strategy contains certain Multiple Intelligence Approach (MIA) (2012: 138). Furthermore, a language classroom should be provided by activities of presentation, practice, memorization, comprehension, application, strategy, affective, feedback, and assessment (Richards and Lockhart, 2009: 162-165).

In English teaching and learning process conducted with MI a teacher must be able of playing role as opportunities provider for students to use all of their intelligences in classroom (Hoer, 2000: 65). A teacher is also a facilitator of students' learning (Chatib, 2012: 75). On the other hand, Brown (2001: 17-18) states the roles of teacher are need analyst, provider of students input, motivator, organizer and controller of students behavior, demonstrator of accurate language production, materials developer, monitor of students' learning, and counsellor and friend.

In MI-based language classroom the studens are the intelligence user of themselves that means provided by chance to be developed within their various intelligences (Hoer, 2000: 65). According to Watkins (2008: 19), students, on the other hand, in language classroom have several roles as active participants in classroom, discoverer, questioners of the learning process and recorder of information.

In MI classroom the materials should be available by the way of visual, auditorial, and kinesthetical (Chatib, 2010: 136). Teaching materials are beneficial in order to allow learners to progress at their own rates of learning, allow for different styles of learning, provide opportunities for independent study and use, provide opportunities for self-evaluation and learning progress.

A teaching and learning process must be completed by evaluation. Brown in Richard and Renandya (2002: 77) identifies evaluation as systematic collection and analysis of all relevant information which do not only emphasize on the learners' achievement but also their attitude toward the learning process. Thus, the evaluation must concern on both the product and the process. There are two kinds of evaluation, those are formative and summative evaluations. Formative evaluation refers to assessing students in the process of forming their competencies and skills in order to help them continue their growth. It implies that the teacher needs to observe the process of learning. Summative evaluation on the other hand, deals with assessing students at the end of a certain period by using exercises or experiences specifically designed to tap into a storehouse of skills and knowledge. (Brown, 2000: 402). Chatib (2010: 155) states that in MI framework, the evaluation must be in the form of authentic assessment that has certain characteristics of emphasizing on the competences which are taught, encouraging the development of the learners with disability, emphasizing on three domains; cognitive, psychomotoric, 
and affective; and using test and non-test in data collecting.

\section{RESEARCH METHODS}

In this research, the researcher used descriptive qualitative method. Based on Picciano (2004: 51), descriptive research involves describing and interpreting events, condition, or situation of the present. Elliot and Kratochwill state that descriptive method as a research in which the investigator examines and reports things the way they are in an effort to understand and explain them (1994: 24). Similarly, Johnson and Cristensen (2000: 32) explained that descriptive research aims at providing accurate description of characteristics of certain situation or phenomenon. The researcher used descriptive research under qualitative method that examines behavior naturalistically in all of its detail. It is appropriate to the aim of this study that is to find out how something occurs in natural setting.

Johnson and Christensen (2000: 17) state that the data of qualitative research are in the form of non-numerical data which are represented in a collection of words and sentences. The data in this research were retrieved from some sources those were: (1) event covering English language teaching and learning process, (2) informants, and (3) document that includes lesson plan, syllabus, book, and students' score sheet.

Meanwhile, the sampling technique in this research is purposive sampling. According to Barreiro and Albandoz, (2001: 4), purposive sampling is the way of selecting sample by using personal opinion or purpose. It is supported by Sugiyono (2010: 300) who says that in selecting the sample the researcher should work based on judgement and consideration. The data were collected through some interview, observation, and document analysis. The data then were checked by the trustworthiness in the form of triangulation. Emzir (2010: 82) says that triangulation is the process of strengthening evidence or findings through different individuals. The data were processed by using interactive analysis model that consists of collecting the data, reducing the data, data display, and drawing conclusion.

\section{RESEARCH FINDINGS AND DISCUSSIONS}

In the planning stage the implementation if MI does not specify certain syllabus of English teaching and learning, but specifies certain model of lesson plan. The English only uses the standard competence and basic competence stated on the textbook. Meanwhile, the lesson plan used by the teacher has special characteristics those are multiple intelligence approach, alpha zone, scene setting, strategy, problems, new ideas and special moment.

On the other hand, within the implementation stage teaching and learning activities basically covers apperception and strategy. Apperception involves the activities of alpha zone, scene setting, warmer, and pre-teach. Meanwhile, strategy is the heading all learning activities which conveys the certain types of students' intelligence. Within the strategy there are learning activities of presentation, practice, memorization, comprehension, strategy, affective, feedback, and assessment, The roles of teacher are facilitator, students input provider, monitor of students' learning, need analyst, motivator, organizer and controller, demonstrator of correct language production, material developer, and; counsellor and friend. Meanwhile, the roles 
of students are participant, active learner, intelligence user, and responder. The materials used by the teacher are in the form of instructional and authentic materials which are provided through auditory, visual, and kinesthetical material.

The teacher did evaluation of teaching and learning process through two aspects those were: (1) the evaluation toward the students' achievement which is done through test including exercises stated on the textbook, daily examination, semester examination, and national examination; and non-test evaluation which is done by the observation toward students' accomplishment and participation during teaching and learning process, (2) the evaluation toward the flow of the the teaching and learning process covering problems, new idea, and special moment.

There were several benefits and challenges in implementing MI. The benefits are: (a) creating fun teaching and learning process, (b) creating effective teaching, (c) promotting students' participation, (d) facilitating the students based on their characteristics. The challenges in implementing $\mathrm{MI}$ in English language teaching are: (a) the difficulties in managing classroom dynamic when all the things that was planned is not well accomplished, (b) threating towards the student with special needs especially in evaluating the achievement of the student.

Based on the research findings, on the planning stage the aspects which were involved were syllabus and lesson plan. The syllabus used was taken from the textbook. Meanwhile, the lesson plan was developed by adapting the syllabus stated on the textbook. It is in fit to the Educational National Legislation Number 41 Year 2007 about Process Standard.Actually, MI is clearly implemented by the arrangement of the lesson plan. on the lesson plan there were found the points of alpha zone, warmer, scene setting, strategy, problems, new idea, and special moment. All of them were appropriate to the concept that was proposed by Chatib (2011: 203). He stated that an MI lesson plan must put header, content, and footer as the biggest parts. The lesson plan must cover aperception involving alpha zone, warmer, and scene setting; strategy, problems, new idea, and special moment. In addition, the lesson plan included several general aspects stated by Indonesia Educational National Legislation those were objectives, teaching material, sources and assessment. But, the lesson plan did not state the method. The existence of method was replaced by strategy. It is because MI does not regard the use of method as a main part of teaching and learning process, instead it puts strategy as the biggest guide of classroom activities. Thus, method could be put under the strategy.

The next stage of the teaching process is implementation. One aspect involved in this stage is learning activities. The learning activities of language classroom conducted by MI framework covered the points apperception and strategy. Apperception itself is defined as the activities that concern on how to make the students pay attention and to trap them in curiousity. In addition, according to Chatib (2012: 87), apperception should be done in the very beginning of the lesson. It is because, the initial time is very determining toward the process to come during the lesson. It influences the condition of the students from the beginning until the end of the lesson so that the result of the lesson will also be affected. Actually, apperception is 
not a single activity. It consists of several types of activity that usually have fun characteristics. In this case, the teacher of a classroom has several types those are alpha zone, warmer, pre-teach, and scene setting.

Based on the data collecting, in English classroom the teacher always began the lesson with alpha zone activities. These activities were conducted through several fun activities, such as games, listening and singing song, and fun-story telling. Alpha zone is a part of apperception. After conducting alpha zone activities the teacher started to teach the material to the students. The teacher always primarily used certain MI strategies conveying intelligence types. The use of strategies determined everything related to the lesson. It is like what was mentioned by Chatib (2012: 87). He stated that in MI teaching and learning, strategy is one of the most two essential parts in teaching and learning process in the classroom, besides apperception. In arranging the lessons the teacher has to vary the activities by the use of various strategies. In teaching, the teacher arranged the lesson activities by the use of various strategies, such as musical strategy, bodily-kinaesthetic strategy, and interpersonal strategy.

Not only alpha zone, but scene setting and warmer which are two types of apperception, were also put within teaching and learning process. Scene setting was implemented in the first meeting of a new teaching topic. While, warmer was found on the lesson plans made by the teacher. It was given on the meeting after the new teaching topic was presented for the first time.

In addition, there were also found the other activities that were stated by Richards and Lockhart (2009: 162-165). The activities which were found in the classroom were presentation activities, practice activities, memorization activities, comprehension activities, strategy activities, affective activities, feedback activities, and assessment activities.

Teaching English means teaching the students how to communicate within the four language skills; listening, speaking, reading, and writing. Murcia (2001:140) stated that in teaching English especially for children, the teacher has to provide the students the activities of LSRW integratively. Actually, in the classroom this theory has been implemented by the English teacher, though they were not given all at once. The teacher usually integrated them by combining some of them, such as listening was combined with speaking and reading was combined with writing.

According to Suyanto (2008: 15-20) one of children's characteristics is that they like to have fun activities. Thus, they always need to be provided with fun condition in their all activities, including learning. This has actually been implemented in the lessons done by the English teacher in her classrooms. In her lessons the teacher always tried to create fun learning that was done through various activities such as games, singing song, body moving, and group work. What was done by the teacher in the relation to creating fun condition for children was actually an impact of the implementation of $\mathrm{MI}$ in teaching and learning process. The characteristic of children to keen on having fun activities was facilitated by the existence of alpha zone and the use of strategies. Alpha zone was aimed at attracting the students in order that they feel fun and happy and trapping their attention and curiosity. So, they would learn well. Meanwhile, the use of strategies enabled the 
teacher to work through many various teaching ways. It provided the teacher the possibilities to vary lesson activities that were fit to students' characteristics.

In implementation stage the teacher held a role as facilitator. This role helped the students to develop themselves within their various intelligences. It is done through the use of strategies which were chosen based on the eight of intelligences. It is in line with the concept proposed by Chatib (2012: 75). He said that an MI teacher must be the students' learning facilitator. Instead of seeing the students as empty vessel that were ready to be passively taught, the teacher puts the students as persons completed by various competences that can be developed by strategies regarding their intelligences.

Furthermore, there were several other teacher roles in the classroom, those were students input provider, monitor of students' learning, need analyst, motivator, organizer and controller, demonstrator of correct language production, material developer, and; counsellor and friend. All of them were fit to the roles that were stated by Brown (2001: 17-18).

On the other hand, the students were also certain roles during their learning. One of the roles held by the students was participant. This role is in line with the role proposed by Watkins (2008: 19). He said that in a language lesson, the students have several roles those were as participant, discoverers, questioners, and information recorder. There was another role of students in the classroom namely active learner. It dealt with the role of the students to give contribution toward teaching and learning process. This role has been proposed by Amstrong who said that in the lesson that is conducted with MI, the central activity is how to provide the students the opportunity to engage in active learning (2009: 109).

Another role of the students which was found in the classroom was intelligence user. This role was conveyed by the use of teaching strategies refered to eight types of intelligence. This is in accordance to the role that has been stated by Hoer. He said that the student is seen as intelligence user. It means that they are intentionally facilitated and organized to manifest and to show their intelligence strength in learning. (2000: 65). In addition the students also shown their role as responder. According to Savignon (in Murcia, 2001: 20), a student learning language, needs to give responses within their learning.

The next component involved in the implementation stage of teaching and learning process is teaching materials. It has been found that the English teacher has tried to deliver materials specifically through the ways which made the materials possible to be retrieved in visual, auditory, and kinaestethical information.

All of those findings were actually in line with Chatib statements. According to him (2010:136), in delivering the materials, an MI teacher has to concern on providing the materials covering the characteristics of visual (e.g.,picture, color, notes, table, mind map, diagram), auditorial (e.g.music, song, stroy telling, dialog), kinaestethical (e.g.,interview, experiment, observation, playing).

Furthermore, the teacher also used instructional materials from the English textbook that was arranged based on government curriculum, KTSP. The textbook consisted of various materials which were completed by exercises. Dealing with instructional material it was stated by Baltimore County Public School (2010: 1) 
that instructional material was defined as those items that are designed to instruct students in the teaching and learning process regardless of delivery method and/or format. Besides, the teacher used authentic materials that were modified by herself. The materials were in the form of songs, flash-card and pictures on power point presentation slides. This type of materials were used to deliver the main topics as well as the instructional materials. In this case, the teacher worked in line with the principle which is stated by Tamo (2009: 1). She said that English materials in language classroom should not only be presented instructionally but also authentically that can be in the form of newspapers, TV programs, the internet, movies, songs, comics, literature, etc.

The evaluation focused not only on the students' achievement but also the process of teaching and learning. Students' achievement was evaluated by test and nontest evaluation. The test was conducted by having the students to do task stated on the textbook, daily examination, semester examination, and national examination. All of them were involved in summative evaluation. On the other hand, there was also used non-test evaluation. It was conducted during teaching and learning process to give feedback, reinforcement and to observe the students accomplishment toward their learning material. Nevertheless, the teacher also observed the students development in accomplishing their learning observation without giving them certain instructions. Both the evaluation types were proposed by Brown (2000: 402). He stated in evaluation stage, the language learners could be assessed by using two ways those were formative and summative evaluations.

Furthermore, the teacher used different way in evaluating the achievement of the students with special needs. The teacher gave the students chance to do what they could do rather than what they could not. Actually, the evaluation done by the teacher was appropriate to the characteristics of evaluation proposed by Chatib (2010: 155). He states that the evaluation should have several characteristics of emphasizing on the competences which are taught, encouraging the development of the learners with disability, emphasizing on three domains; cognitive, psychomotoric, and affective, and using test and non-test in data collecting.

Meanwhile, the evaluation toward the process was done through finding the special moment. Special moment was aimed at finding unusual thing related to the students' learning. Together with special moment, the evaluation also concerned on recognizing the problem rising in the lesson. After that, the teacher was expected to find new ideas to overcome the problem. The evaluation of the process was stated on the lesson plan containing some blank sheets that would be filled after the lesson had been done. This kind of evaluation fulfilled the characteristic of MI teaching and learning proposed by Chatib. He stated that in implementing MI in teaching and learning process, the teacher must focus on special moment, although it is not always found. He also stated that special moment is written on the ending part of lesson plan. In addition, he included the problems and new ideas points on the same part. (2011: 201-203).

\section{CONCLUSIONS AND SUGGESTIONS}

The result of the research shows that in planning stage the teacher provides lesson plan which is arranged based on MI characteristics. Meanwhile in implementation stage the teacher should concern on providing the teaching and 
learning process by the activities that basically cover apperception and strategy. Apperception covers activities of alpha zone, scene setting, pre-teach, and scene setting. Strategy concerns on determining how the lesson should be arranged based on certain Multiple Intelligence Approach. In implementation, the teacher play roles as facilitator, input provider, monitor of learning, need analyst, motivator, organizer, controller, language demonstrator, material developer, and counsellor. On the other hand, the the students play roles as participant, active learner, intelligence user, and responder. In addition, the teacher uses instructional and authentic materials in teaching.

In conducting MI-based evaluation, an English teacher concerns on the product and process of learning. The product refers to the achievement of the students, while the evaluation of the process concerns on finding problems, new idea, and special moment.

The use of MI in elementary English classroom makes the teaching and learning process fun, lively and effective. The students in the classroom enthusiastically and actively participate in their activities. Furthermore, the implementation of MI eases the students to obtain the standard score of English.

However, the implementation of MI raises problems. Ssometime, it is difficult to create appropriate classroom activities to all the students. Inappropriateness between the decisions made by the teacher and the students makes the classroom dynamic run unwell. In addition, implementing MI creates difficulties for the teacher in the relation to students. The treatment during classroom activities and the evaluation process toward the student with special needs.

Therefore, it is suggested for the teacher to be provided by competence enrichment of MI classroom management and teaching students with special needs. On the other hand, for the school it is recommended to divide the students into different classrooms based on their intelligence strength in order to ease teacher in managing the classroom. For the Education Ministry it is recommended to include MI in the national curriculum to reconstruct the government education rules especially in English teaching and learning to be multiple intelligence-based curriculum.

\section{BIBLIOGRAPHY}

Armstrong, Thomas.(2009).Multiple Intelligences in the Classroom. $3^{\text {rd }}$ edition. USA:ASCD publication.Association for Supervision and Curriculum Development,Alexandria.

Attard, Angele., Emma Di lolo, Koen Geven, and Robert Santa. (2010) Student Centered Learning: An Insight Into Theory and Practice.Bucharest: Education International.

Barreiro, Paula L. and Puerto Albandoz, Justo. (2001) Population and Sample, Sampling Techniques. Seville: University of Seville.

Brown, Douglas. (2001). Teaching by Principles: An Interactive Approach to Language Pedagogy 2nd Ed. New York: Addison Wesley longman, inc.

Brown, H Douglas. (2000). Principles of Language Learning and Teaching. New Jersey: Prentice Hall. 
Cameron, Lynne. (2001). Teaching Languages to Young Learners. Cambridge: Cambridge University Press.

Chatib, Munif. (2012). Gurunya Manusia. Bandung: Mizan Pustaka

Chatib, Munif.(2010). Sekolahnya Manusia:Sekolah Berbasis Multiple Intelligences di Indonesia. Bandung: Mizan Pustaka

Clark, John. (1997).Teaching Children :is it difficult? New York: Mac Millan.

Elliot, Stephen., Kratochwill, Thomas, Littlefield, Joan \& Travers, John. (1999). Educational Psychology (Effective Teaching and Effective Learning). New York: Brown and Benchmark

Emzir. (2010). Metode Penelitian Kualitatif: Analisis Data. Jakarta:Rajawali Pres.

Enco, Mulyasa. (2007). Kurikulum Tingkat Satuan Pendidikan. Bandung. Remaja Rosdakarya.

Harmer, J. (2001). The Practice of English Language Teaching. London: Longman Group Limited.

Hoerr, Thomas R.. (2000). Becoming a Multiple Intelligences School. USA:

Johnson, Burke and Larry Christensen. 2000. Educational Research: Quantitative and Qualitative Approaches. USA: Allyn \& Bacon.

Murcia, Marrianne Celce. (2001).Teaching English as a Second or Foreign Language. USA:Heinle and Heinle.

Richards ,Jack C. and Willy A. Renandya. (2002). Methodology in Language
Teaching: An Anthology of Current Practice. New York: Cambridge University Press.

Richards, Jack C. and Charles Lockhart. (2009). Reflective Teaching in Second Language Classroom. New York: Cambridge University Press.

Suyanto, Kasihani K.E. (2008). English for Young Learners. Jakarta: Bumi Aksara.

Tamo, Daniela. (2009). The Use of Authentic Materials in Classrooms. Article: LCJP. Vol.:2

Watkins, Peter. (2005). Learning to Teach English. Surrey: Delta Publishing

Widdowson, H.G.2008 Teaching Language as Communication. New York:Oxford University Press.

Zhu, Honglin.2011. The Application of Multiple Intelligences Theory in Task-based Language

Teaching.Vol:1,No.4,pp.408-412.

Finland:Academic Publisher.

(2006).Standar Isi untuk Satuan Pendidikan Dasar dan Menengah: Standar Kompetensi dan Kompetensi Dasar SD/MI. Jakarta :BSNP. 